J. Product. \& Dev., 17(2): 239 - 255(2012)

\title{
LEAF SURFACE FEATURES AS TAXONOMIC EVIDENCES TO IDENTIFY SOME SPECIES OF GENUS EUCALYPTUS IN EGYPT BY USING SCANNING ELECTRON MICROSCOPE
}

\section{Hanan S. Abd-El Maksoud ${ }^{1}$; M. M. E. Abd El-Kader ${ }^{2}$ and Nermeen T. Shanan ${ }^{3}$}

1.Flora and Phyto-taxonomy Department, Research Hort., Research Institute, A.R.C., Giza, Egypt.

2.Forestry Department, Research Hort., Research Institute, A.R.C., Giza, Egypt.

3. Ornamental Department Hort., Faculty of Agriculture, Cairo University, Giza, Egypt.

\section{ABSTRACT}

Morphological characters and ultrastructural leaf variations of nine species belong to genus Eucalyptus were studied. These species are; Eucalyptus camaledulensis, E. cinerea, E. citriodora, E. ficifolia, E. globules, E. gomphocephala, E. kruseana, E. resinfera and E. rostrata.

The macro-morphological characters revealed that, there are different leaf shapes; each characterized more than one species. The micro-morphological results of upper epidermis clarified that there are five sharply distinct leaf sculpture patterns; Pusticulate, Ruminate, Glebulate, Colliculate and Favulariate. While that of the lower epidermis had six leaf sculpture patterns; Ruminate, Verrucate, Verculate, Rugose, Favulariate and Clliculate, except one species, where the leaf has sculpture pattern overlaphing between Ruminate and Favularlate.

The artificial key has been designed to identify the studied species. However, this study can be serve as a limited taxonomic knowledge about the studied and may be useful in other future studies.

Conclusively, from the pervious results of such research it could be conclude that the more close species to each other were; E. ficifolia and E.globules; E.resinfera and E.rostrata. Contrary, the most far species from each other were E.cinerea and E.krusean.

Key words: Macro \& micro morphological characters, SEM, Eucalyptus 


\section{INTRODUCTION}

The Eucalyptus, a widespread genus of the family Myrtaceae, covers more than 50\% of Australian territory (Pryor and Johnson 1971).

Eucalyptus genus includes 900 species and its subspecies spread considerably in many countries (Brooker and Kleingi, 2004). Eucalyptus species are believed to be introduced in Egypt during the 1800's, (El-Lakny et. al., 1980). They are highly adapted to local environmental condations and grow very fast. These species are traditionally planted as windbreaks, for shade and to supply wood for lumber, particleboard and charcoal production as well as to produce of medical and aromatic components . A mature Eucalyptus may take the form of a low shrub or a very large tree. There are three main habit and four size categories that species can be divided into. Eucalypts are called "sclerophyllous" which means 'hard leaves'. They hang vertically so they are not exposed to the midday sun which reduces water loss through transpiration.

Tree size based on the following criteria; small $(10 \mathrm{~m})$, medium $(10$ $30 \mathrm{~m})$, tall $(30-60 \mathrm{~m})$ and very tall (over $60 \mathrm{~m})$. The bark, leaves and reproductive structures are greatly varied in different species (Brooker and Kleingi, 1996 ). The bark is of three kinds; 1 . Soft and brittle (shedding in short irregular flakes, lacking in fibre), 2. Hard and long-fibred (shedding in long broad, thick flakes or strips and 3. Very thin and finely fibred (shedding in ribbons). The leaves are of 3 kinds; passing through juvenile, intermediate and mature stages (Humphries et al., 1981).

Nearly all Eucalyptus species are evergreen but some tropical species lose their leaves at the end of the dry season. As in other members of the myrtle family, Eucalyptus leaves are covered with oil glands. Many Eucalyptus species are heteroblastic; producing juvenile and adult leaves differing markedly in morphology and anatomy ( Johnson 1976; Pryor ,1976). Juvenile leaves are commonly sessile, decussate, glaucous, oriented horizontally, discolorous (dorsiventral) and often cordate, orbicular or ovate in shape. Size and shape of juvenile leaves in particular are important taxonomic characters in Eucalyptus (Pryor, 1976; Phillips and Reid ,1980; Potts and Reid ,1965 and Wiltshire et al., 1991) . Adult leaves tend to be petiolate, alternate, glabrous, pendulous, lanceolate and concolorous (isobilateral ) (Coppen, 1996).

Many micro-characters have diagnostic value only when characterizing lowest taxonomic categories (e.g. many types of cuticular striations, most of the frequent types of cell shapes, many types of widely distributed epicuticular crystalloids). There are many characters could be used to characterize groups of related species, genera or taxonomic categories up to the sub-family levels. Some characters of the micro-morphology and orientation of epicuticular wax crystalloid are surprisingly high systematic significance. Wax platelets may 
have parallel orientation patterns resembling electromagnetic field lines around the stomata. This pattern called Convallaria-type (Cole and Benhnke, 1975 and Barthlott, 1981). Dhalgren (1975) indicated the distribution of wax type (hatched) in the revised classification of angiosperms.

Carr and Carr ( 1979 ) found that closure line of stoma in fully grown adult leaves of certain eucalyptus is formed by special ridges of cuticle called 'stomatal bars' developed at the line of closure itself or from up growth of the cuticle of the lower surface of the guard cells. Stomatal bars were previously discovered in three members of the informal group 'Bisectae' and were shown to be restricted to certain species in that group. Possession of stomatal bars may affect stomatal performance but does not appear to be a general adaptive response to the habitats of the species which possess them. Mrobably, the possession of stomatal bars is an inherited character with taxonomic value. Barclay and Watson (1998) revised species of genera Carum and Trachyspermum (umbelliferae) by using SEM and the classical morphology . Results showed that these endemic species should be treated as one variable species; trachyspermum pimpinelloides. Ostroumove (1990) studied the stomata types on leaves of some species belong to tribes coriandreae and scandiceae (umbelliferae) in relation to taxonomy. Szujko-lacza (1994) studied the leaf characters of coriandrum sativum.

El-Khanagry (2003) purposed a key to identify 49 species of grasses belong to 33 genera by using vegetative of leaves as well as trichomes and cuticular ornamentations. However, leaf morphological characters have been used for identification purposes. With increased sophistication of classification systems, it has become increasingly important to have more elaborative means for identification. The leaf has not lost its importance as a taxonomic tool but rather has proved to be more useful when a fuller understanding of all its characteristics are known and appreciated.

The objective of such research was to find out remarkable micro and macro-morphological leaf features which could be used by further studies as taxonomic evidences reflecting the taxonomic relationship between the studied species.

\section{MATERIALS AND METHODS}

This study was carried out during 2010 - 2011 seasons on fresh juvenile and adult leaves of nine species of genus Eucalyptus (Table 1). Taxonomical evidences and characters which will explore the relationships between the studied species were gathered from morphological descriptions for each species and from the taxonomic of leaf surface using Scanning 
Table 1. The studied species and the collection regions.

\begin{tabular}{|c|c|c|c|}
\hline No. & Scientific name & English name & Regions \\
\hline 1. & $\begin{array}{l}\text { Eucalyptus } \\
\text { camaledulensis } \\
\text { Dehnh. }\end{array}$ & $\begin{array}{l}\text { Red Gum, Murray Red } \\
\text { Gum, River Red Gum }\end{array}$ & $\begin{array}{l}\text { Experimental field of } \\
\text { Faculty of Agriculture Cairo } \\
\text { University, Giza Zoo and } \\
\text { Experimental Field of El- } \\
\text { Kassasin Horticulture } \\
\text { Research Institute, } \\
\text { Agricultural Research } \\
\text { Center }\end{array}$ \\
\hline 2. & Eucalyptus cinerea & $\begin{array}{l}\text { Argyle Apple, Mealy } \\
\text { Stringybark, Silver } \\
\text { Dolar }\end{array}$ & $\begin{array}{l}\text { Experimental Field of } \\
\text { Faculty of Agriculture Cairo } \\
\text { University }\end{array}$ \\
\hline 3. & $\begin{array}{l}\text { Eucalyptus citriodora } \\
\text { Hooker }\end{array}$ & Lemon Gum & $\begin{array}{l}\text { Experimental Field of } \\
\text { Faculty of Agriculture Cairo } \\
\text { University and } \\
\text { Experimental Field of El- } \\
\text { Kassasin Horticulture } \\
\text { Research Institute, } \\
\text { Agricultural Research } \\
\text { Center }\end{array}$ \\
\hline 4. & Eucalyptus ficifolia & Red Flowering Gum & Al Salhiah Algadida \\
\hline 5 & $\begin{array}{l}\text { Eucalyptus globules } \\
\text { Labill. }\end{array}$ & $\begin{array}{l}\text { Tasmanian Blue Gum, } \\
\text { Eurabbie }\end{array}$ & Giza Zoo \\
\hline 6 & $\begin{array}{l}\text { Eucalyptus } \\
\text { gomphocephala }\end{array}$ & Tuart & $\begin{array}{l}\text { Experimental Field of El- } \\
\text { Kassasin Horticulture } \\
\text { Research Institute, } \\
\text { Agricultural Research } \\
\text { Center }\end{array}$ \\
\hline 7 & Eucalyptus kruseana & Book-leaf Mallee & Al Salhiah Algadida \\
\hline 8 & Eucalyptus resinfera & $\begin{array}{l}\text { Red Mahogany, Red } \\
\text { Messmate }\end{array}$ & Giza Zoo \\
\hline 9 & Eucalyptus rostrata & & Giza Zoo \\
\hline
\end{tabular}


Electron Microscope (SEM) on leaf surface. All data were subjected to using numerical analysis technique called NTSYS-PC.", version1.5 program (Rohlf, 1993) which resulted in a form of dendrogram representing the relationships among the studied species. Also, artificial keys using the posterior characters were designed.

\section{- Preparing the leaf surface samples for SEM exam}

Upper and lower surfaces of adult leaves of each species were examined by using Scanning Electron Microscope (SEM). Leaf samples were prepared before examination at National Research Center, Giza. as follows:

- Fixation and Dehydration. The specimens were mounted on copper stubs with double-sides adhesive tape and coated with gold using Sputter Coater S 150 A Edwards-England. The specimens were examined under JXA- 840A Electron Probe Microanalyzer- JEOL-JAPAN. Terminology concerning description leaf surface pattern was adopted after Stearn (1983) and Barthlott and Frolich (1984).

Obtained data of micro and macro morphological studies on the leaf surfaces were analyzed by using a Single Linkage Clustering analysis technique (Sneath and Sokal, 1973). Final results of analysis were represented in a form of dendrogram.

\section{RESULTS AND DISCUSSION}

Data of species under consideration were gathered from the two main sources; i.e., macro-morphological description of leaves (juvenile and adult) and micro-morphological description of adult leaf surfaces (upper and lower surfaces) and were represented in Tables 2 and 3.

\section{1- Macro-morphological descriptions of leaves.}

Results in Table 2 revealed that there are five different shapes and three sizes of leaves among the nine studies eucalyptus species as follows

Shape 1- Lanceolate shape characterized the leaves of four species; $E$. camaledulensis , E. citriodora, E. globules and E. resinfera. The leaf lengths of these species were up to $17 \mathrm{~cm}$, with acute apex and symmetrical base, except E. globules with asymmetrical base.

Shape 2- Oval lanceolate shape characterized leaves of E. ficifolia. Leaf length was ranged between $6-17 \mathrm{~cm}$, with acute and symmetrical leaf apex and base. 
Shape 3- Ovate lanceolate shape in E. gomphocephala. The leaf length reached up to $17 \mathrm{~cm}$, with acute apex and very asymmetrical base.

Shape 4- Ovate to widely ovate shape was restricted in two species; $E$. cinerea and E.rostrata. The leaf length and shape of apex and base of the first species were less than $6 \mathrm{~cm}$, acuminate and cordate. While in the second species were between $6-17 \mathrm{~cm}$, apiculate and symmetrical.

Shape 5- Raniformis leaf shape distinguished only in E. krusean with leaf length less than $6 \mathrm{~cm}$, with obtuse apex and reniform base.

Moreover leaves of all species were petiolate, alternate and leathery texture leaves, except those of E. krusean which were sessile, opposite and not leathery in texture.

Based on the leaf thickness, the studied species split into two categories; thick leaves in four species; i.e., E. citriodora, E. ficifolia, E. globules and E. gomphocephala and thin leaves in five species; i.e., E. camaledulensis, E. cinerea, E. kruseana, E.resinfera and E.rostrata.

\section{2- Microrphological description of leaves}

A- Upper epidermis:

There are five sculpture patterns of the leaf upper epidermal surface of the nine studied species (Table 3 and Plates 1and 2):

Pattern 1- Pusticulate as in E.camaledulensis, E. ficifolia and E. rostrata

Pattern 2- Ruminate as in E. cinerea and E. citriodora.

Pattern 3- Colliculate as in E. gomphocephala and E. resinfera.

Pattern 4- Glebulate as in E. globules

Pattern 5- Favulariate as in E. krusean

$B$ - Lower epidermis:

There are six sculpture patterns of the leaf lower epidermal surface of the studied species (Table 3):

Pattern 1- Verruculate as in E. camaledulensis, E. resinfera and E. rostrata. Pattern 2- Favulariate as in E. cinerea and E. krusean.

Pattern 3- Ruminate - favulariate as in E. ficifolia.

Pattern 4- Ruminate as in E. globules.

Pattern 5- Rugose as in E. citriodora.

Pattern 6- Colliculate as in E. gomphocephala.

\section{Numerical analysis}

Illustrated dendrogram in Figure (1) shows level of similarity in which the studied species have been shared, in other words, determining the similarity or dissimilarity distance between these species. However, it could 

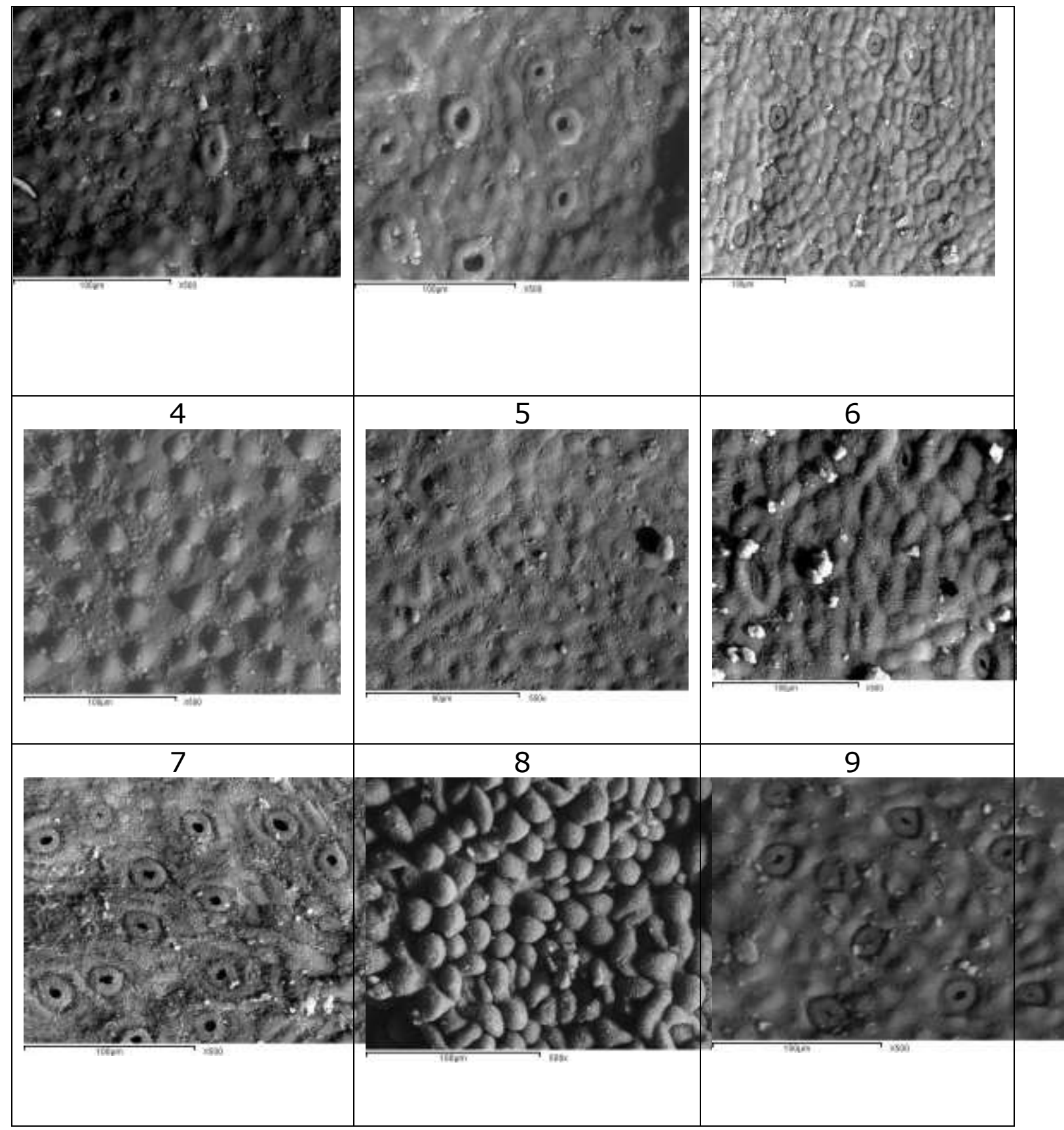

Plate.1: Leaf upper epidermal surface as shown under the SEM

Key: 1) E.camaledulensis

4) E. ficifolia

7) E.krusean
2) E.cinerea

5) E.globules

8) E.resinfera
3) E.citriodora

6) E.gomphocephala

9) E.rostrata 


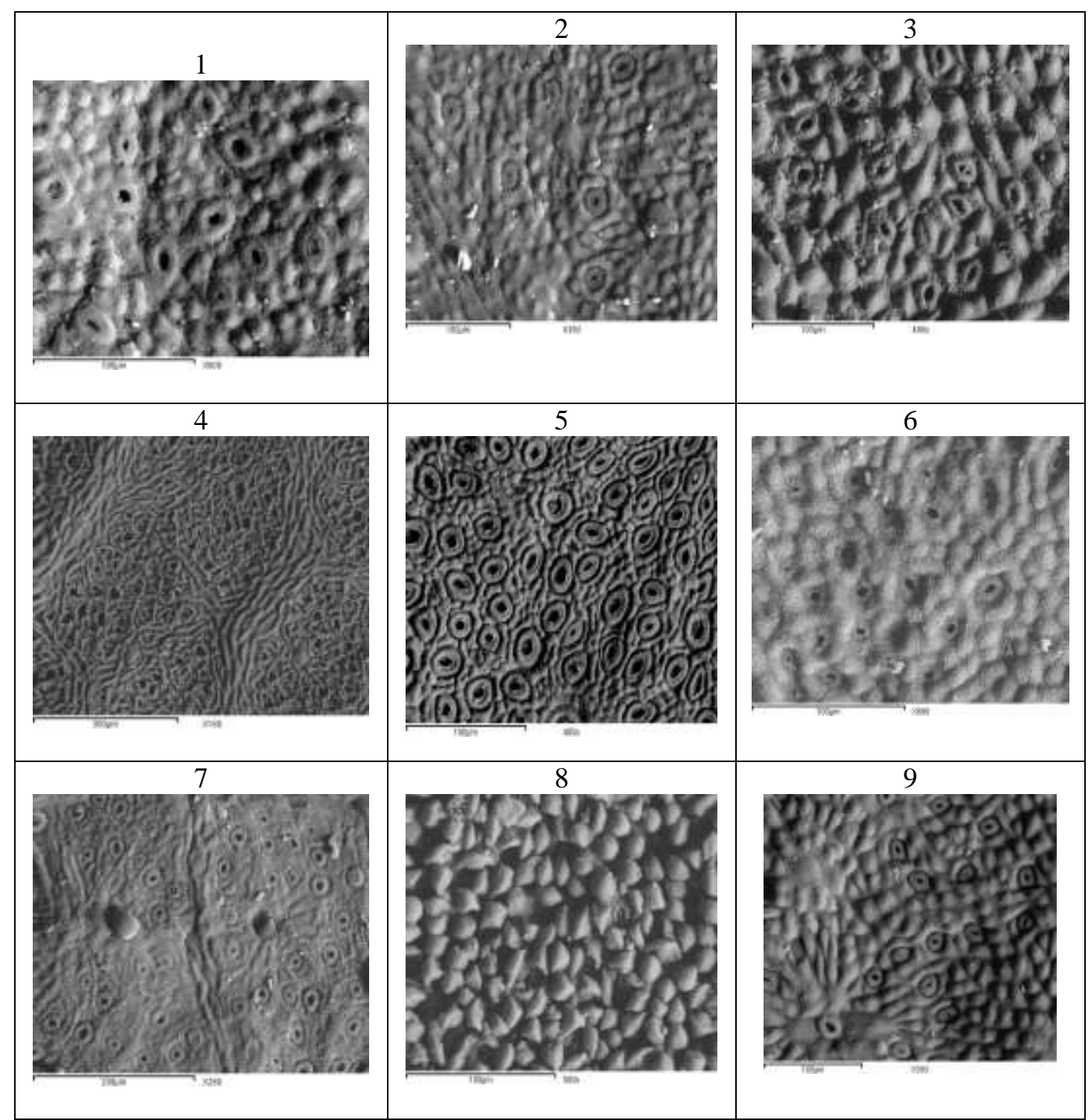

Plate2: Leaf lower epidermal surface as shown under the SEM
Key: 1) E.camaledulensis
2) E.cinerea
3) E.citriodora
4) E. ficifolia
5) E.globules
6) E.gomphocephala
7) E.krusean
8) E.resinfera
9) E.rostrata 


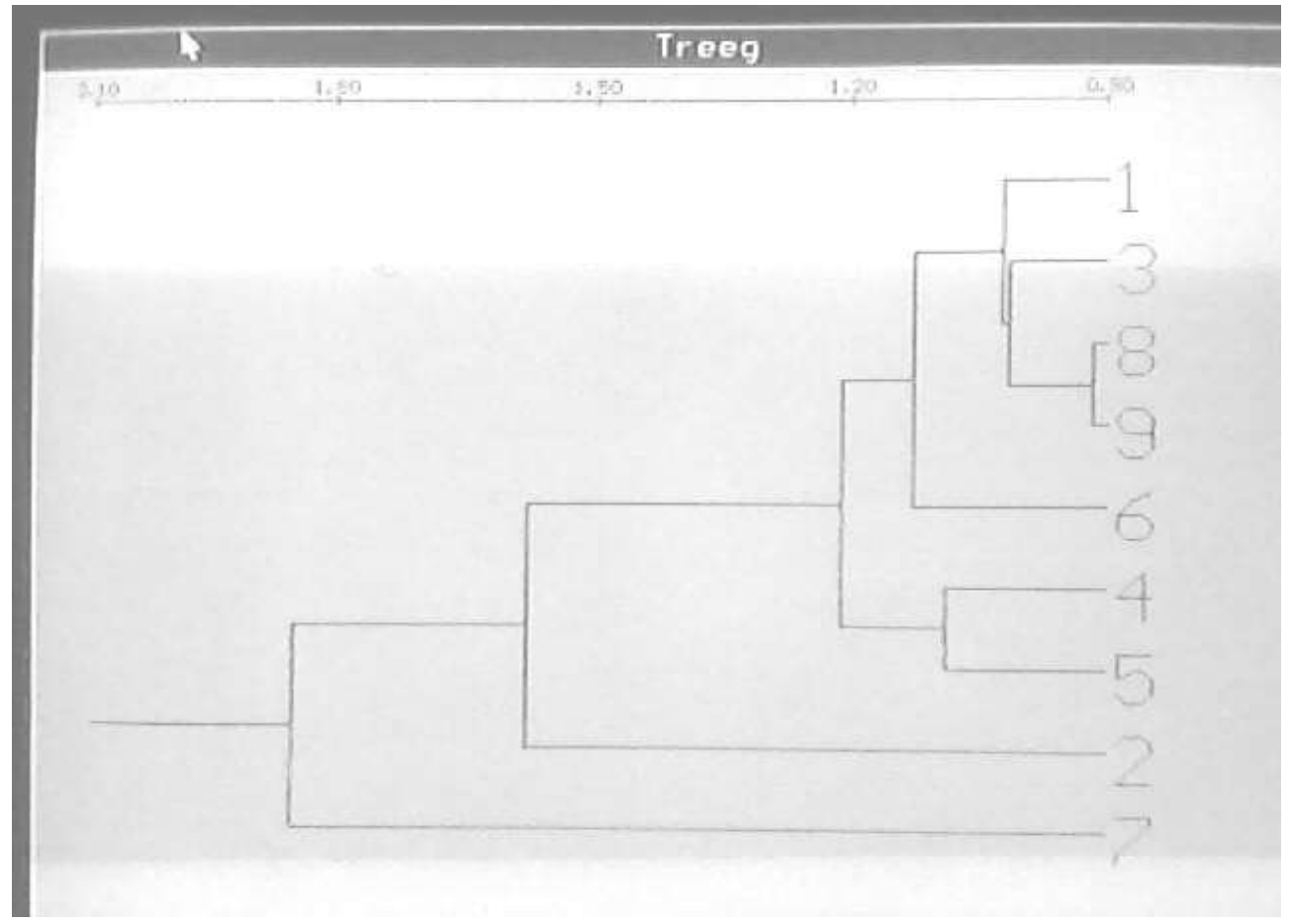

Figure 1. Dendrogram of operational taxonomic units (otus) based on macro- and micromorphological attributes using numerical analysis

Key : The following key was proposed based on the macro and micro morphological characters of leaves to distinguish the studied species.

A) Juvenile and adult leaves are the same in outline shape.

b) Leaf reniformis, opposite, sessile, obtuse apex, reniform base. Upper surface of epidermis weak favulariate, stomata depressed. Lower surface of epidermis favulariate, stomata superficial. ..E. kruseana

bb) Leaf ovate, petiolate. Juvenile leaf opposite. Adult leaf alternate, apiculate apex, symmetrical base. Upper surface of epidermis pusticulate, stomata semidepressed. Lower surface of epidermis verrucate, stomata depressed............................E. eostrata

AA) Juvenile and adult leaves are different in shape.

c) Juvenile and adult leaves are alternate, petiolate, apex acute.

d) Very asymmetrical base. Upper and lower surfaces of epidermis colliculate, stomata depressed.......................... gomphocephala. 
dd) Symmetrical base, with light veins. Upper surface of epidermis pusticulate, stomata absent. Lower surface of epidermis ruminate- favulariate, stomata superficial. ..E. ficifolia

cc) Juvenile leaf opposite and adult leaf alternate.

e) Petiolate, apex acute symmetrical base.

f) Upper surface of epidermis colliculate, stomata absent. Lower surface of epidermis verrucate, stomata very depressed .E. resinfera

ff) Upper surface of epidermis ruminate, stomata depressed. Lower surface of epidermis rugose, stomata depressed.......E. citriodora

ee) Petiole absent in juvenile leaf but adult leaf petiolate,

g) Apex acuminate, cordate base. Upper surface of epidermis weak ruminate, stomata very raissed. Lower surface of epidermis favulariate, stomata smiraised. E. cinerea .

gg) Apex acute,

h) Asymmetrical base, light green. Upper surface of epidermis glebulate, stomata absent. Lower surface of epidermis ruminate, stomata E. globulus

hh) Symmetrical base, dull and bluish green. Upper surface of epidermis weak pusticulate, stomata . Lower surface of epidermis verruculate, stomata raised in two surface E. camaledulensis

be stated that the studied species, according to the similarity or dissimilarity distance, split into three main clusters. The very far cluster which started at the highest similarity level (1.70) included E.krusean. The second cluster, which started at similarity level quit closer to the previous cluster, included E.cinerea. while the third cluster split into three sub clusters. The first included two species; E. ficifolia and E.globules where they shared at 1.10 similarity level. The second subcluster included only one species; E.gomphocephala where it joined with the third subcluster at 1.17 similarity level. The latter subcluster included four species; E.resinfera and E.rostrata joined together at 0.93 similarity level, while E.citriodora joined with the previous two species at 1.03 . The fourth species; E.camaledulensis joined with E.citriodora, E.resinfera and E.rostrata at 1.06 similarity level. The third cluster with all subclusters linked with the second cluster at 1.57, then all linked with the first cluster at 1.70 similarity level as they all species belong to the same genus and family.

Conclusively, from the pervious results of such research it could be conclude that the more close species to each other were; E. ficifolia and E.globules; E.resinfera and E.rostrata. Contrary, the most far species from each other were E.cinerea and E.krusean. 


\section{Appendices}

Appendix 1. Characters and characters states list for numerical analysis of the studied species.

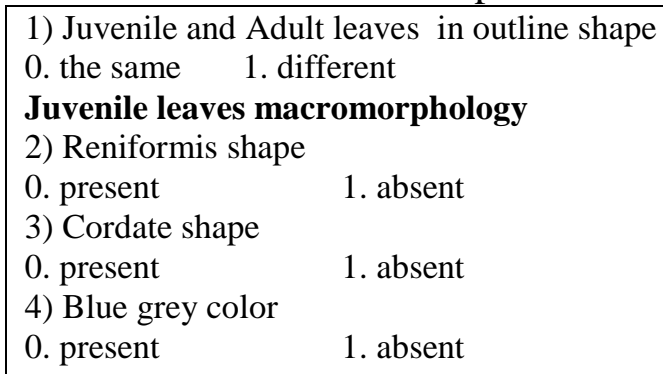

5) Petiole

0 . present

1. absent

6) Leaf Arrangement

0. Opposite

1. Alternate

Adult leaves macromorphology

7) Reniformis shape

0 . present

1. absent

8) Leaf length

1. more than $6 \mathrm{~m}$

0. less than $6 \mathrm{~cm}$.

1.more than $6 \mathrm{~m}$.

9) Leaf colour

1.not so

0 . Silvery white

$1 . \operatorname{tot}$ so

0. light Veins

1. not so

11) Petiole
0 . present
1. absent

12) Leaf Arrangement

0 . Opposite

1. Alternate

13) Leaf Thickness

0.Thin

1. Thick

14) Leaf texture

0 . Leathery

1. not so

15) Leaf acut apex

0 . present

1. absent

16) Leaf acuminatet apex
0 . present
1. absent

17) Leaf obtuse apex

0 . present 1 . obsent

18) Leaf apicular apex

0 . present

1. obsent

19) Leaf symmetrical base

0 . present 1. absent

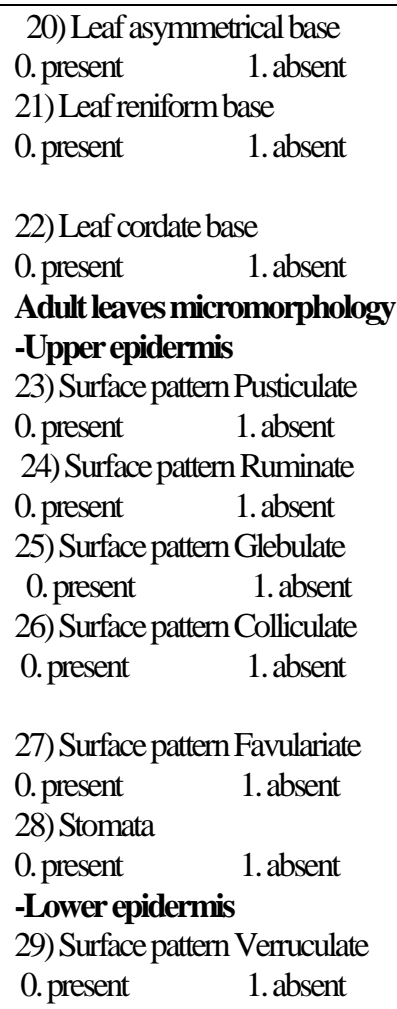

30) Surface pattern Favulariate 0 . present 1. absent 31) Surface pattern Rugose 0 . present 1. absent 32) Surface pattern Ruminate 0 . present 1. absent 33) Surface pattern Colliculate 0 . present 1. absent 34) Surface pattern Verrucate 0 . present 1. absent 35) Somata leveling raised 0 .present 1 . absent

36) Somata leveling depressed 0.present 1. absent 37) Somata leveling Superficial 0.present 1 . absent 
Appendix 2. The characters descriptions, character states and codes for the Numerical analysis.

\begin{tabular}{|c|c|c|c|c|c|c|c|c|c|}
\hline $\begin{array}{l}\text { Species } \\
\text { Characters }\end{array}$ & 1 & 2 & 3 & 4 & 5 & 6 & 7 & 8 & 9 \\
\hline 1 & 1 & 1 & 1 & 1 & 1 & 1 & 0 & 1 & 0 \\
\hline 2 & 1 & 1 & 1 & 1 & 1 & 1 & 0 & 1 & 1 \\
\hline 3 & 1 & 0 & 1 & 1 & 1 & 1 & 1 & 1 & 1 \\
\hline 4 & 1 & 0 & 1 & 1 & 1 & 1 & 0 & 1 & 1 \\
\hline 5 & 0 & 1 & 0 & 0 & 1 & 0 & 1 & 0 & 0 \\
\hline 6 & 0 & 0 & 0 & 1 & 0 & 1 & 0 & 0 & 0 \\
\hline 7 & 1 & 1 & 1 & 1 & 1 & 1 & 0 & 1 & 1 \\
\hline 8 & 1 & 0 & 1 & 1 & 1 & 1 & 1 & 1 & 1 \\
\hline 9 & 1 & 0 & 1 & 1 & 1 & 1 & 0 & 1 & 1 \\
\hline 10 & 1 & 1 & 1 & 0 & 1 & 1 & 1 & 1 & 1 \\
\hline 11 & 0 & 0 & 0 & 0 & 0 & 0 & 1 & 0 & 0 \\
\hline 12 & 1 & 1 & 1 & 1 & 1 & 1 & 0 & 1 & 1 \\
\hline 13 & 0 & 0 & 1 & 1 & 1 & 1 & 0 & 0 & 0 \\
\hline 14 & 0 & 0 & 0 & 0 & 0 & 0 & 1 & 0 & 0 \\
\hline 15 & 0 & 1 & 0 & 0 & 0 & 0 & 1 & 0 & 1 \\
\hline 16 & 1 & 0 & 1 & 1 & 1 & 1 & 1 & 1 & 1 \\
\hline 17 & 1 & 1 & 1 & 1 & 1 & 1 & 0 & 1 & 1 \\
\hline 18 & 1 & 1 & 1 & 1 & 1 & 1 & 1 & 1 & 0 \\
\hline 19 & 0 & 1 & 0 & 0 & 1 & 1 & 1 & 0 & 0 \\
\hline 20 & 1 & 1 & 1 & 1 & 0 & 0 & 1 & 1 & 1 \\
\hline 21 & 1 & 1 & 1 & 1 & 1 & 1 & 0 & 1 & 1 \\
\hline 22 & 1 & 0 & 1 & 1 & 1 & 1 & 1 & 1 & 1 \\
\hline 23 & 0 & 1 & 1 & 0 & 1 & 1 & 1 & 1 & 0 \\
\hline 24 & 1 & 0 & 0 & 1 & 1 & 1 & 1 & 1 & 1 \\
\hline 25 & 1 & 1 & 1 & 1 & 0 & 1 & 1 & 1 & 1 \\
\hline 26 & 1 & 1 & 1 & 1 & 1 & 0 & 1 & 0 & 1 \\
\hline 27 & 1 & 1 & 1 & 1 & 1 & 1 & 0 & 1 & 1 \\
\hline 28 & 0 & 0 & 0 & 1 & 1 & 0 & 0 & 1 & 0 \\
\hline 29 & 0 & 1 & 1 & 1 & 1 & 1 & 1 & 1 & 1 \\
\hline 30 & 1 & 0 & 1 & 0 & 1 & 1 & 0 & 1 & 1 \\
\hline 31 & 1 & 1 & 0 & 1 & 1 & 1 & 1 & 1 & 1 \\
\hline 32 & 1 & 1 & 1 & 0 & 0 & 1 & 1 & 1 & 1 \\
\hline 33 & 1 & 1 & 1 & 1 & 1 & 0 & 1 & 1 & 1 \\
\hline 34 & 1 & 1 & 1 & 1 & 1 & 1 & 1 & 0 & 0 \\
\hline 35 & 0 & 0 & 1 & 1 & 1 & 1 & 1 & 1 & 1 \\
\hline 36 & 1 & 1 & 0 & 1 & 1 & 0 & 1 & 0 & 0 \\
\hline 37 & 1 & 1 & 1 & 0 & 0 & 1 & 0 & 1 & 1 \\
\hline
\end{tabular}
Key: 1) E.camaledulensis
E.cinerea
3) E.citriodora
4) E. ficifolia
5) E.globules
6) E.gomphocephala
7) E.krusean
8) E.resinfera
9) E.rostrata 


\section{GLOSSARY}

Sculpture of surface:

Colliculate:With rounded broad elevations closely spaced covering the seed - coat.

Favulariate: With the surface finaly ribbed, the ribs separated by zigzag furrows

Glebulate: With small clumps of irregularly placed granules. Lineate : marked with fine lines.

Pusticulate: With small broad slight elevations not so high or a bundant as on a colliculate surface and not having as a brupt elevations as a minutely tuberculate surface.

Rugose: Wrinkled, the irregular elevation making up the wrinkles and running mostly in one direction.

Ruminate: Penetrated by irregular channels giving an eroded appearance and running in different directions.

Verrucate: With irregular projections or knobs.

Verruculate: With closely spaced tiny irregular projections.

Type of stomata:

Actinocytic type : The stomata is surrounded by epidermial cells which are uniformally arranged along the radii of a circle.

Anomocytic type: The stomal pores surrounded by unmodified epidermal cells of varying size which are irregularly arranged and can not be differentiated from the other epidermal cells.

Type of Trichomes ( Glandular):

Belladonna : It contains uniseriate multicellular stalk and head.

Mentha: It contains short stalk with multicellular headand unicellular stalk

Vasaka: It contains unicellular glandular trichomes in which stalk is absent.

\section{REFERENCES}

Barclay, E.L. and Watson, M.F. (1998). A revision of Carum and Trachyspermum (Umbelliferae) in the Socotran Archipelago. Kew Bulletin, 53 (4): 897-907.

Barthlott, W. (1981). Epidermal and seed surface characters of plants: Systematic applicability and some evolutionary aspects. Nordic Journal of Botany, Copenhagen, (1): 345-355

Barthlott, W. and Frolich, J. (1984). Micro-structural features of seed surfaces (ed. V. H. Heywood \& Moore, D. M.), Academic Press, London. p. 95-105

Brooker, M.I.H. and D.A. Kleinig, 1996: Field Guide to Eucalyptus. Vol. 1, Bloomings Books, Hawthorn, Victoria, South-Eastern Australia. 
Brooker, M.I.H. and D.A. Kleinig, 2004: Field Guide to Eucalyptus. $2^{\text {nd }}$ ed., Vol. 3, Melbourne Blooming Books, Northern Australia.

Carr, S. G. M. and Carr, D. J. (1979). An Unusual Feature of Stomatal Microanatomy in Certain Taxonomically- related Eucalyptus spp_Annals of Botany Company ${ }_{\llcorner}$Oxford Journals, 44, Issue2,pp. 239-243.

Cole, G. T. and Benhnke, H. D. (1975). Electron Microscopy and Plant Systematics. Taxon, 24: 315.

Coppen, A. (1996). Eucalyptus, An illustrated guide to identification, Reed Books, Melbourne,

Dhalgren, R. (1975). A system of classification of the Angiosperms to be used to demonstrate the distribution of characters. Botaniska Notiser, 128: 119- 147

El-Khanagry, S.S.G. (2003). Field key for identification of some Egyptian grasses by vegetative characters. The $2^{\text {nd }}$ Conference of Agriculture \& Biological Research Division, National Research Center, Egypt, 3: 547-557.

El-Lakany , M.H.;M.L.M.El-Osta and O.A.Badran (1980).Evaluation of newly introdced Eucalyptus camaldulensis provenances in Egypt . Alex . J. Agric. Res., 28 (3): 309-319.

Humphries, C. J. , Press, J. R. and Sutton, D. A. (1981). Trees Of Britain and Europe. The Hamlyn Publishing Group Limited. 320Pp.

Johnson, L.A.S., 1976: Problems of species and genera in Eucalyptus (Myrtaceae). Plant Syst. Evol., 125: $155-167$.

Ostroumove, T.A. (1990). Stomatal types in the Umbelliferae in relation to taxonomy of tribe Conianreae \& Scandiceae. Fedds Report, 101 (7-8): 409416

Phillips, R. L. and Reid, J. B. (1980). Clinal variation btween Eucalyptus viminalis Labill. and Eucalyptus dalrympleana Maiden. Australian Journal of Botany, 28: 329-342.

Potts, B. M. and Reid, J. B. (1965). Variation in the Eucalyptus gnii-archerii complex.11 The origin of variation. Australian Journal of Botany, 33: 519541.

Pryor, L. D. (1976). The biology of Eucalyptus. Edward Arnold, London, U. K. pp82

Pryor, D. and A.S. Johnson, 1971: "A Classification of the Eucalypts". Australian National University: Canberra.

Rohlf, F. J. (1993). NTSYS-PC. Numerical Taxonomy And Multivariate Analysis System. Exeter Software, New York.

Sneath, H.A. and R.R. Sokal (1973). Numerical Taxonomy the Principles and Practice of Numerical Classification. Freeman and Co., San Francisco. pp. 359

Stearn, W.T. (1983). Botanical Latin, $3^{\text {rd }}$ Edit. David \& Charles Inc. , USA. pp. 553 
Szujko-Lacza, J. (1994). Architecture and inner structure of the cariandram sativum L., Akademial Kiado. Budapest, Prielle Korneliau, pp. 19-35.

Wiltshire, R. J. E. Potts, B. M. and Reid, J. B. , (1991). Apaedomorohocline in Eucalyptus: Natural variation in the E. risdonii/ E. tenuiramis complex. Australian Journal of Botany, 39: 545-566.

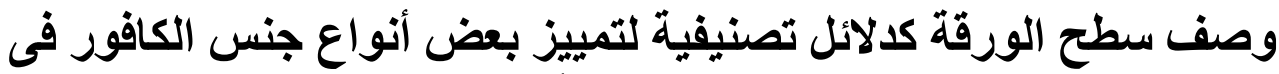

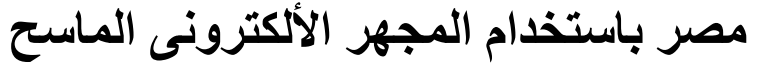

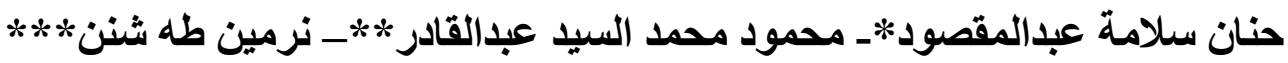

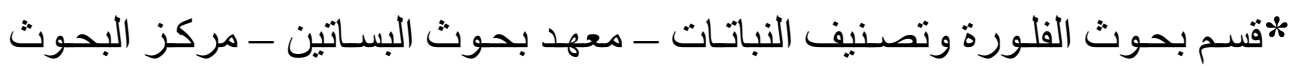

$$
\begin{aligned}
& \text { الزر اعية ـ مصر. }
\end{aligned}
$$

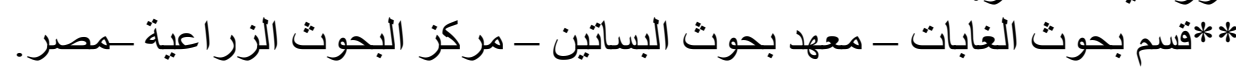

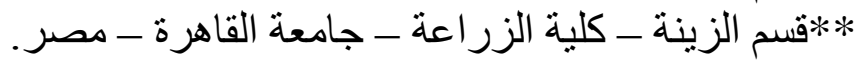

$$
\text { درست جنس الصافور، كانت هذه المورولية والانواعتلاف البنائى الدقيق لسطح الورقة لتسعة أنواع }
$$

Eucalyptus camaledulensis, Eucalyptus cinerea, Eucalyptus citriodora, Eucalyptus ficifolia , Eucalyptus globules, Eucalyptus gomphocephala, Eucalyptus kruseana, Eucalyptus resinfera and Eucalyptus rostrata.

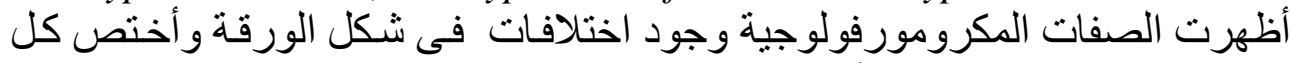

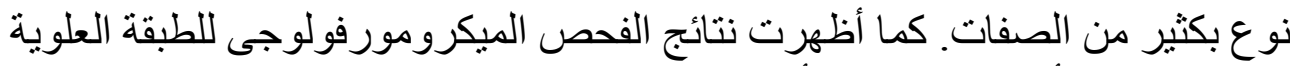

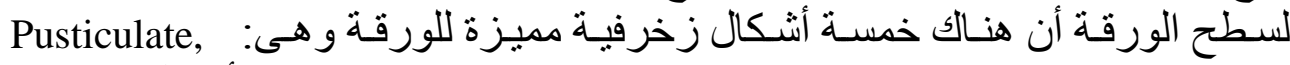
مuminate , Glebulate, Colliculate , Favulariate

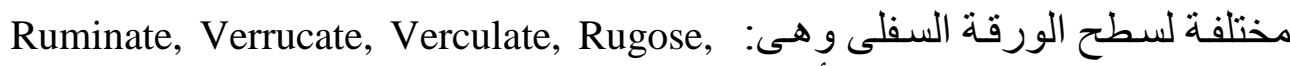
زجavulariate , Clliculate

$$
\text { زخرفيين هما : Ruminate - Favularlate }
$$

$$
\text { وقد صمم مفتاح اصطناعى للفصل بين الأنو اع اع المدروسة. }
$$

التوصية : تم التتويه بامكانية ان تخدم هذه الدراسة كمعلومات تلقسيمية للبحوث المدرو 